\title{
Northwest of Suez: The 1956 Crisis and the IMF
}

\begin{abstract}
JAMES M. BOUGHTON*
Egypt's nationalization of the Suez Canal in 1956 and the failed attempt by France, Israel, and the United Kingdom to retake it by force constituted a serious political crisis with significant economic consequences. For the United Kingdom, it engendered a financial crisis as well. That all four of the combatants sought and obtained IMF financial assistance was highly unusual for the time and had a profound effect on the development of the IMF. This case study illustrates the complexities in isolating the current account as the basis for determining a balance of payments "need" and shows that the speculative attack on sterlingand the IMF's response to it-were remarkably similar to financial crises in the 1990s. [JEL F33, F34, N20]
\end{abstract}

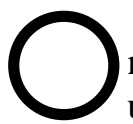

n July 26, 1956, Egypt nationalized the Suez Canal Company and unilaterally assumed control of the canal from the international consortium that had run it for nearly a century. France, Israel, and the United Kingdom almost immediately began planning a joint military action to retake control, while they sought to win international support for a diplomatic solution. When diplomacy failed, Israel invaded the Sinai on October 29, and France and Britain used Egypt's counterattack as an excuse to attack Egypt by air from the Mediterranean two days later. The fighting shut down the canal, which was the major shipping channel between Europe and Asia and a vital link in the transport of petroleum from the Middle East. One week later, however, Britain undercut the operation by accepting a United Nations resolution for a

*This paper was prepared while I was on leave at St. Antony's College, University of Oxford. I would like to thank Shailendra Anjaria, Keith Kyle, Jacques Polak, Gregor Smith, John Toye, and anonymous referees for comments on earlier drafts. 
ceasefire. On December 3, the British government announced that it would withdraw its troops over the next few weeks. France and Israel soon also withdrew, and Egypt reopened the canal under its own control the following April.

That this brief flare-up is universally regarded as a crisis is primarily because of the upheavals it engendered in political relations. It successfully climaxed Egypt's longstanding campaign for full independence from European dominance. It demonstrated Israel's ability to defend and expand its borders militarily and thus to survive as a nation. It weakened France just as the Algerian war was intensifying. It exposed a rift in relations between Britain and the United States over postcolonial policies at a time when both wanted to counter the rising regional influence of the Soviet Union. In Britain, it brought a sad end to the brief ministry of Anthony Eden and ironically elevated Harold Macmillan in his place. In view of the central place of Suez in the mythology of the British Empire-Eden had once called it "our back door to the East," and generations had grown up on Kipling's evocation of an uninhibited life "somewheres east of Suez"- the loss of control over the canal was devastating for those with lingering Victorian aspirations. In the Middle East, it solidified Gamal Abdel Nasser's budding leadership role and hinted-if only temporarily-at the possibilities for Arab unity. A vast and still-growing literature has analyzed each of these facets in exquisite detail. ${ }^{1}$

The economic consequences of Suez were more subtle and temporary and would not by themselves have constituted an international crisis. Notwithstanding the crucial importance of the canal for certain trade flows, the economic impact of its closing was limited by its short duration. By October, Egypt had already proved that it could run the canal safely and efficiently without European assistance. For the six months that the canal was closed, the resulting cost increases, delivery delays, and trade diversion weakened the current account positions of all four of the combatants, but normalcy was largely restored within another six months. ${ }^{2}$

For the United Kingdom, Suez was also a financial crisis. Throughout 1956 and 1957, Britain had a current account surplus despite the disruptions to its international trade. The value of its currency, however, came under speculative pressure, and the Bank of England was forced to deplete its U.S. dollar reserves to defend the fixed value of the pound sterling against the dollar. Macmillan (then Chancellor of the Exchequer) and Cameron Cobbold (Governor of the Bank of England) put on a brave front in characterizing the Bank's ability to stave off an attack, but by December the threat of a forced devaluation or float was very real.

${ }^{1}$ For a chronology, analysis, and basic bibliography of political events affecting the canal and AngloEgyptian relations from the 1850s to the crisis and its ramifications, see Gorst and Johnman (1997). For a full recounting and analysis of the crisis, see Kyle (1991); the "back door" quotation is on p. 7. Farnie (1969) provides a detailed history of the canal and its central place in the British Empire.

2On the general economic aspects of the crisis, see Kunz (1991). Johnman (1989) analyzes the economic effects on the United Kingdom. Also see IMF (1957), pp. 27-30, which notes that the economic effects were less severe than had been anticipated. 
These events unfolded at a time when the IMF was almost totally untested in crisis management. From its first financial operations in 1947 to the onset of the Suez crisis, the IMF had lent only sporadically and in small amounts. ${ }^{3}$ The concept of stand-by lending subject to agreed policy conditions was still being developed and had been applied in only a few cases. ${ }^{4}$ The little financing that was being provided was mostly either gold tranche drawing (that is, countries were temporarily drawing out the reserve assets that they had deposited on becoming members) or was limited to the first credit tranche (that is, countries were borrowing no more than 25 percent of their quota, an amount equivalent in size to their paid-in gold tranche). In the two years preceding the Suez crisis, the IMF did almost no lending: drawings for 1954-55 totaled $\$ 90$ million by just five countries (Colombia, Indonesia, Iran, Mexico, and the Philippines). Most of that was in the gold tranche. Only Mexico had a stand-by arrangement, and only the Philippines drew in the upper tranches (that is, borrowed more than the first credit tranche). In these circumstances, it was not obvious that the IMF should play any role at all in the resolution of the economic or financial difficulties of the countries involved in Suez.

A further reason not to anticipate significant IMF involvement was that the country with the gravest financial difficulties — the United Kingdom—did not obviously qualify for IMF assistance in 1956. The IMF's Articles of Agreement prohibit it from lending to finance a "large and sustained" outflow of capital, which in essence was what Britain faced. That provision was intended to preserve the IMF's limited financial resources for lending to promote international trade in goods and services. ${ }^{5}$ Moreover, if the speculative outflow from sterling was not both large and sustained, the Bank of England had enough resources of its own and enough access to credit that it could fend off the outflow without IMF assistance.

In addition to these factors, the IMF was in an interregnum during the crucial months of October and November and was missing its customary European leadership. Ivar Rooth, a former central bank governor from Sweden, completed his five-year term as Managing Director at the end of September. His

\footnotetext{
3For 1947 through 1955, 14 of the IMF's 59 members made drawings on the IMF (excluding gold tranche purchases), averaging $\$ 46$ million per annum (equivalent to 0.06 percent of world imports). For comparison, for 1990-98, 78 of the IMF's 182 members made drawings on the General Account (excluding those in the reserve tranche), averaging $\$ 13,367$ million ( 0.29 percent of world imports). Although the reserve tranche is formally equivalent to the old gold tranche (that is, it represents the member's paid-in reserves), drawings on it cannot be compared. Gold tranche drawings were treated as temporary and had to be repaid within specified periods; reserve tranche drawings need not be repaid.

${ }^{4}$ The first stand-by arrangement in which drawings were made conditional on the country adhering to specified policies was for Peru in 1954. That practice was gradually refined and made more general over the next several years but did not become standard practice until well into the 1960s. See Boughton (2001), Chapter 13, for an elaboration and further references.

5The "commentary" prepared by the U.S. Treasury in 1944 to explain the purposes and operations of the proposed IMF expressed this point clearly. "In considering the probable attitude of the Fund toward the sale of foreign exchange to facilitate a transfer of capital, it should be borne in mind that the provisions of the Fund proposal are designed to give effect to the general principle that the Fund's resources should be used primarily for settling international balances on current account.” Horsefield (1969), Vol. 3, p. 167.
} 
compatriot Per Jacobsson-then a senior official at the Bank for International Settlements (BIS) — was not due to arrive until December. Consequently, the Deputy Managing Director, H. Merle Cochran of the United States, was in charge when the IMF was called upon to respond to a series of politically sensitive financing requests.

Despite these obstacles, the IMF was called upon to help finance the external payments imbalances of all four combatants (Table 1). Over the course of nine months, it lent $\$ 858$ million to those four countries and committed itself to another $\$ 738$ million in credits on a stand-by basis. This paper reviews how the IMF came to be so heavily involved and analyzes the implications for its later role as an international crisis manager. Those implications stem primarily from the rescue of the pound sterling from a speculative attack: the first major financial crisis of the postwar era.

\section{Conventional Financing: Egypt, Israel, and France}

In the space of four weeks in September and October 1956, the IMF received financing requests from three of the four countries engaged in the Suez crisis. Each case was treated as a conventional problem of financing a temporary payments imbalance arising from the current account. None of these three countries had a convertible currency, and speculative pressures were unimportant. Each involved political complications, but ultimately the IMF was able to act upon them without becoming embroiled in the crisis.

\section{Egypt}

Egypt's economic difficulties intensified on September 13 when the government was forced to assume operations of the canal. The European boat pilots, on instructions from their former employers, abruptly walked out in an attempt to prove to Egypt that international control was necessary. Egypt, however, was determined to keep the canal open, and it brought in Egyptian pilots to take over. With costs rising and revenues plummeting, Egypt submitted a formal request to the IMF eight days later.

Since joining as an Original Member in 1945, Egypt would be drawing on IMF resources for only the second time. On the first occasion, in April 1949, it had drawn only 5 percent of its quota ( $\$ 3$ million), and it had repaid the credit the following year. Now it was requesting only to draw the full amount of its gold tranche (25 percent of quota, or $\$ 15$ million). Formally, then, this was a routine request, necessitated by the presumably temporary pressure on Egypt's balance of payments from the disruption in international trade. The only real question was whether politics would intrude.

By coincidence, the Annual Meetings of IMF and World Bank Governors were just about to begin in Washington when the Egyptian request came in on September 21. The next afternoon, the Executive Board convened in a rare Saturday session, at the Sheraton-Park Hotel where the Governors' meetings were being held. Egypt's Executive Director, Ahmed Zaki Saad, presented the case for 
NORTHWEST OF SUEZ: THE 1956 CRISIS AND THE IMF

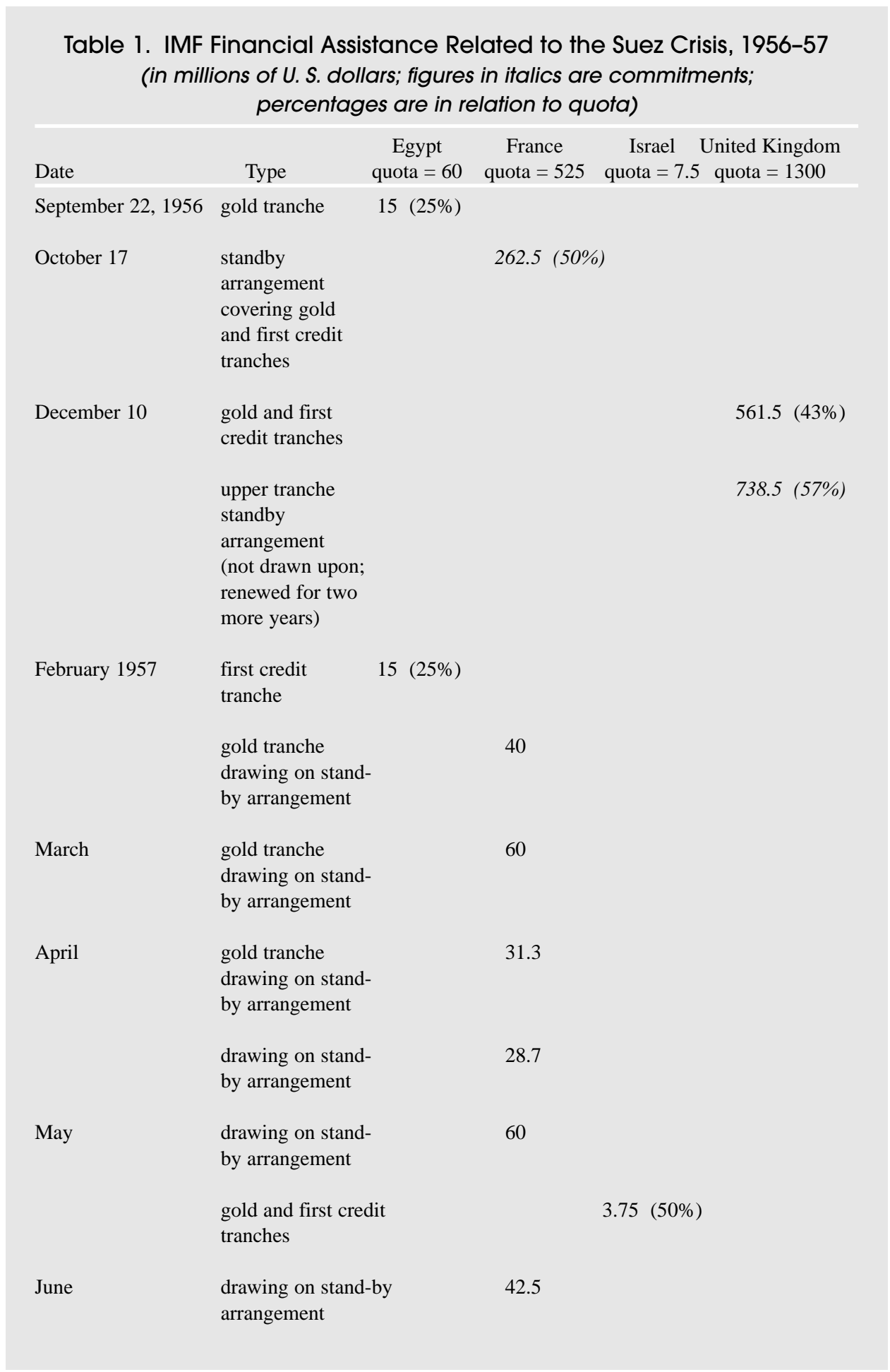


the request. The U.S. Director (Frank Southard) spoke in favor, and the French Director (Jean de Largentaye) consented by noting the absence of any legal basis for objecting. The British Director (William Edward, Lord Harcourt) abstained, as did the Netherlands chair. The official decision stated simply that the IMF "expresses no objection" to the request. At the suggestion of the Canadian Director (Louis Rasminsky), Rooth agreed that no public announcement would be made of this transaction. ${ }^{6}$ In this manner, despite the delicacy of the circumstances, the IMF rapidly approved its first Suez-related financing.

Israel

A few days later, the Governor of the Bank of Israel, David Horowitz-also in Washington for the Annual Meetings-made informal inquiries about enlarging and then drawing on Israel's IMF quota. The request was temporarily rebuffed, for reasons that were partly economic and partly political.

In September, when Horowitz made his request, no one in the IMF had any knowledge about the secret arming of Israel by France or about the emerging invasion plans. The initial difficulty therefore was largely economic. When Israel had joined the IMF in 1954, the staff had expressed concerns that the economy was not yet stable enough to sustain a fixed rate of exchange for its currency. The IMF therefore had discouraged Israel from setting a par value, a step that it viewed as a prerequisite for drawing on IMF resources. ${ }^{7}$ For several months now, the Israeli authorities had been pushing the IMF to initiate the process for determining an appropriate value, but the staff had resisted. Israel was maintaining, and was gradually trying to dismantle, a complex system for external transactions. Most transactions took place at an exchange rate of 1.8 Israeli pounds per dollar, but the prevalence of bilateral trade agreements, subsidies, and multiple exchange rates meant that repressed inflation was likely to be a serious problem. In these circumstances, it was difficult for the IMF to assess whether 1.8 was a sustainable rate.

On October 22, the staff position shifted reluctantly from skepticism toward acceptance of 1.8 for Israel's exchange rate. Although the staff analysis still suggested that Israel would have difficulty holding that rate for very long, the Director of the European Department (Gabriel Ferras) accepted the government's argument that fixing the rate would provide a nominal anchor for wage negotiations and thus would help stabilize prices. Moreover, Israel clearly could benefit from drawing on IMF resources to supplement its foreign exchange reserves, and setting a par value would help pave the way. The Acting Managing Director, Merle

${ }^{6}$ IMF/CF, C/Egypt/1710, "Exchange Transaction 1948-59." The Egyptian request was circulated in the document EBS/56/28, "Use of the Fund's Resources-Egypt" (September 21, 1956), and the Board's discussion and decision are in the minutes of Executive Board Meeting 56/48 (September 22).

${ }^{7} \mathrm{~A}$ standard clause in resolutions approving new memberships prohibited the member from drawing on IMF resources until after a par value had been approved. That prohibition could be altered or waived, but in this case the chances for approval were not strong. See IMF/CF, C/Israel/1000, "Par Values and Exchange Rates 1948-75"; memorandum for files by Roman L. Horne, Secretary of the Fund (October 11, 1956). 
Cochran, then placed the matter on the Executive Board agenda for discussion on October $31 .{ }^{8}$

The timing could not have been worse. After Israel invaded the Sinai on October 29, Cochran sensed that any discussion of IMF assistance to Israel would raise a political firestorm. On the morning of October 30, he went to see the U.S. Executive Director, Frank Southard, who agreed that the request should be pulled from the agenda if possible. Then he spoke with Peter Lieftinck, the Executive Director for the Netherlands who also represented Israel on the Board. Lieftinck was in a ticklish position, because the Israeli authorities wanted him to press to keep their request alive. Nonetheless, he followed his own instincts and agreed that Cochran should cancel the discussion.

The record shows clearly that the postponement of Israel's request was purely a response to concerns about the political implications. Cochran explained to Southard that his suggestion was a response "to Israel invading Egyptian territory." Lieftinck's view was similar, and his preference was "that the matter be kept from coming before the Board, at least until after there might be some outcome of the Israeli-Egyptian question consideration by the United Nations." 9

On economic grounds, the staff also retreated from the earlier endorsement of the exchange rate proposal. The military buildup for the Sinai invasion was seen as likely to crowd out domestic investment and contribute to inflationary pressures, which would eventually force a severe tightening of policies or a devaluation. ${ }^{10}$ With hindsight, one can see that this concern was overstated, because the buildup was being partly financed in secret by France. The IMF, of course, was not informed of that relationship. ${ }^{11}$

Despite the widespread international opposition to Israel's military action, the IMF's reluctance to act was soon overcome by the restoration of normal leadership in the institution. Almost as soon as Jacobsson took over as Managing Director in December, he overruled the staff and instructed them to put the discussion of Israel's par value back on the Board agenda. From then on, matters proceeded almost routinely. The staff dutifully produced a favorable recommendation on the proposed exchange rate of 1.8 per dollar, and the Board approved the proposal in mid-March 1957 (one week after Israel withdrew its forces from the Sinai), with Egypt abstaining. ${ }^{12}$

One other element in this process is worth noting, as it further illustrates the interplay of economic and political factors in the IMF's response to Suez. Israel's quota in the IMF, established in 1954, was extremely small and had been set primarily so as to be commensurate with existing quotas for neighboring countries

\footnotetext{
${ }^{8}$ Op. cit., memorandum from Ferras to Cochran, "Israeli par value" (October 22, 1956).

${ }^{9}$ Op. cit., memorandum for files by Cochran (October 30 and 31, 1956).

${ }^{10}$ Op. cit., memorandum from Marcin R. Wyczalkowski (Division Chief in the European Department) to Ferras, "Israel: Par Value Consultations" (November 20, 1956).

${ }^{11}$ France, Israel, and Britain officially denied the relationship for many years, until details of the planning finally became known. The full story of the unwinding of secrecy is told in Shlaim (1997). Kyle (1991) details the French military support for Israel, which he likens to lend-lease (p. 268).

${ }^{12}$ The more favorable view was not unwarranted. Israel maintained its exchange rate at 1.8 until February 1962, when it devalued to 3.0.
} 
(Jordan, Lebanon, and the Syrian Arab Republic). At \$4.5 million, it was near the bottom of the distribution and well below the range suggested by the standard formulas in use at the time (\$9-\$16 million). ${ }^{13}$ In 1956, in the context of the second Quinquennial Review of quotas, the Israeli authorities requested a substantial increase, to at least $\$ 18$ million. Although the IMF did not deny that such an increase seemed warranted by the size and structure of Israel's economy, the staff demurred on the grounds that "the governing factors in this case were overwhelmingly political." 14 In particular, if the Board agreed to raise Israel's quota, neighboring countries would almost certainly submit similar requests, and the rest of the distribution would be difficult to maintain. As it happened, the Board had already agreed to raise all small quotas, on request, to a minimum of $\$ 7.5$ million. Effective in March 1957, that increase was all that Israel could get. ${ }^{15}$

Israel's desire to borrow from the IMF was thus delayed until after the Suez crisis had ended, and even then its quota and therefore the amount it was entitled to borrow was kept small. Undaunted, Horowitz made a second attempt in May 1957. The staff now recommended approval and noted euphemistically that "developments in the Mediterranean" and the consequent rise in military spending had contributed to a worsening balance of payments position. Other factors also were important, including adverse market conditions for Israel's exports and the effects of a surge in immigration, especially from Hungary and Poland, where the suppression of uprisings against Soviet control was causing many to flee. As the staff judged that the government was making a reasonable effort to overcome these developments, the use of IMF resources was appropriate.

The Executive Board met on May 15 to consider Israel's request to draw 50 percent of its quota (the gold tranche and first credit tranche). Three Directors spoke in favor: Lieftinck, Southard, and Julio Gonzalez del Solar (Alternate Director, Guatemala). One abstained (Albert Mansour, the Alternate for Egypt), and the others were not recorded as speaking and were counted in favor. In the end, the handling of the request was essentially routine. ${ }^{16}$

\section{France}

A third overture at the 1956 Annual Meetings came from the Governor of the Bank of France, Wilfrid Baumgartner. On Thursday, September 27, Baumgartner called on Rooth to alert him to the possibility that France might soon need to request a sizable stand-by arrangement. Reserves were low and falling rapidly, as the franc

\footnotetext{
${ }^{13}$ Israel's quota was the same as Lebanon's, larger than Jordan's (\$3 million), and smaller than Syria's ( $\$ 6.5$ million). For the political and economic background, see the papers in IMF/CF, C/Israel/1200, "Quota"; and memorandum from John M. Stevens (Director of the European Department) to Rooth, "Israel's Quota" and attachment (March 16, 1956), in C/Israel/1210, "Quota Adjustment—Increase 1957." ${ }^{14}$ See the memorandum cited in footnote 7.

${ }^{15}$ See Horsefield (1969), pp. 389-91. In the next three general quota increases (1966, 1970, and 1978), Israel obtained increases that were well above average and that finally brought its quota in line with its economy.

16IMF/CF, C/Israel/1710, "Exchange Transactions 1956-75." See EBS/57/26, "Use of the Fund's Resources-Israel” (May 10, 1957), and Sup. 1 (May 13); and minutes of Executive Board Meeting 57/21 (May 15).
} 
was being subjected to "a flight of capital which, however, is not serious at present." Rooth, who had just one week left as Managing Director, made a note for the record but took no further action. ${ }^{17}$

Two weeks later, the French Executive Director, de Largentaye, followed up on Baumgartner's hint by informing Edward M. Bernstein, the IMF's Director of Research, that France wished to enter into a stand-by arrangement for 50 percent of its quota. Although this commitment would be no larger than the one to Israel in relation to the borrower's quota, it would be the largest financial commitment in the IMF's fledgling history (\$262.5 million). Moreover, the Executive Board had declared France to be ineligible to use IMF resources in 1948, and although the declaration had been lifted in 1954, France-like Israel—still lacked an approved par value for its currency. ${ }^{18}$ One might therefore expect the request to have been treated with particular care, but in the event it was processed without undue delay. Whether the IMF would have been more reluctant if it had known of the secret plans that France was developing for the invasion of Egypt is difficult to judge.

The staff was able to move quickly in recommending approval of the French request, because a mission team had recently returned from Paris where it had reviewed economic and financial developments for the annual consultation report required under Article XIV of the IMF's Articles of Agreement. ${ }^{19}$ The mission's analysis of the economy focused-probably correctly-entirely on issues other than Suez.

The dominant adverse influence on the French balance of payments was the war in Algeria. In addition, severe frosts early in the year had sharply reduced agricultural output. Discussions of these and more general issues took place in Paris in July, before the nationalization of the canal, but even in mid-October neither the staff nor the Executive Board saw any need to raise the question of whether the Suez crisis was likely to disrupt the French trade or payments positions. ${ }^{20}$ As a corollary, Baumgartner's citation of capital flight as the basis for the request was never raised as an issue. ${ }^{21}$ The Board unanimously approved France's request for a stand-by arrangement on October 17.22

\footnotetext{
${ }^{17} \mathrm{IMF} / \mathrm{CF}, \mathrm{C} /$ France/1760, "Stand-by Arrangements 1952-57"; note for files, initialed by Rooth (October 1, 1956)

${ }^{18}$ Horsefield (1969), pp. 200-02 and 412. The IMF did not approve a new par value for France until after the currency reform of December 1958.

${ }^{19}$ The original Articles, as written at Bretton Woods, provided for a transitional period in which member countries could gradually dismantle existing controls on the transfer of currencies for current account transactions. Countries availing themselves of that provision (which included most members) were required to consult with the IMF on their progress in moving toward full convertibility. That provision was rewritten in the 1978 amendment, after which all member countries were required to hold regular consultations under the provisions of Article IV.

${ }^{20}$ Even later, the IMF viewed Suez as essentially irrelevant for the French economy. Following a visit to Paris in June 1957, Jacobsson stressed the effects of Algeria and mentioned Suez only en passant as a brief disturbance. IMF/CF, C/France/420, "Stabilization Program 1957"; unsigned and undated note by Jacobsson, "The French financial position, as seen by a visitor to Paris in June 1957."

${ }^{21}$ Because the franc was not a convertible currency, capital flight would have taken the form predominantly of "leads and lags" in settlement of current transactions.

${ }^{22}$ See IMF/CF, C/France/420.1, "Exchange Restrictions Consultations-1955/1956"; SM/56/61, "1956 Consultations-France" (August 23, 1956) and Sup. 1 (October 12), and minutes of Executive Board Meeting 56/51 (October 17).
} 


\section{The British Financial Crisis}

The fourth Suez-inundated country to turn to the IMF was the United Kingdom, under rather different circumstances from the others. France's current account position was estimated to have deteriorated by $\$ 1.1$ billion in 1956 , from a $\$ 409$ million surplus to a $\$ 700$ million deficit, while Israel's deficit had widened by $\$ 75$ million to $\$ 358$ million. Egypt's current account balance had not yet deteriorated, but its prospects had been hit hard by the loss of canal revenues and by large internal expenditures by the Suez Canal Company. In contrast, the United Kingdom registered a current account surplus of $£ 159$ million in the first half of 1956, and the authorities expected a small surplus in the second half as well. In the event, the surplus turned out to total $£ 245$ million in 1956 (slightly higher than the previous year) and a similar magnitude in $1957 .{ }^{23}$ Moreover, because the British had the second-largest quota in the IMF, after the United States, they had the potential to place a serious drain on the IMF's stock of usable currencies (lendable funds). If the IMF aimed to conserve its resources for operations in support of current account balances, it would have to look carefully at the justification for extending credit to the United Kingdom.

The British problem, in a nutshell, was speculation that the Bank of England would have to abandon the sterling parity, which had been set at $\$ 2.80$ in 1949.24 Maintaining that rate was important for several reasons. The government viewed $\$ 2.80$ as appropriate for trade purposes, it feared the inflationary consequences of having to pay expensive dollars for oil imports while the canal was closed, and it regarded exchange rate stability as essential for preserving the sterling area as a preferential trade zone and sterling's broader role as a reserve currency. Although the United Kingdom had not yet established full external convertibility (it would do so in 1958), its system of capital controls was fragmented and porous. The pound was widely held as a reserve and investment medium and thus-in contrast to the other currencies affected by Suez-was subject to speculative pressure. The problem was compounded by the transparency of the reserve position, which the government published each month. The official reserve target since the late 1940s was to maintain a minimum balance of $\$ 2$ billion ( $\$ 2,000$ million). To fall through that floor would be interpreted in financial markets as a signal that devaluation or even floating would have to be seriously considered. ${ }^{25}$

\footnotetext{
${ }^{23}$ For these contemporaneous current account estimates and projections, see the following documents in IMF/CF: "1956 Consultations: Supplementary Information and Revised Recommendations," SM/56/61, Sup. 1 (October 12, 1956), p. 1, in C/France/420.1, "Exchange Restrictions Consultations1955/1956"; "Egypt—Recent Economic Developments and Changes in the Restrictive System," EBS/57/8 (January 30, 1957), pp. 18-21, in C/Egypt/1710, "Exchange Transactions 1948-59"; "Use of the Fund's Resources-Israel," EBS/57/26, Sup. 1 (May 13, 1957), in C/Israel/1710, "Exchange Transactions 1956-75"; and "1957 Consultations-United Kingdom," SM/57/101 (December 10, 1957), p. 28, in C/United Kingdom/420.1, "Exchange Restrictions Consultations 1957."

${ }^{24}$ The Bank of England was obliged by the IMF Articles of Agreement to maintain the value of the pound sterling within 1 percent of the par value, viz. in a range from $\$ 2.772$ to $\$ 2.828$. The Bank, however, had undertaken publicly to maintain a narrower band, from $\$ 2.78$ to $\$ 2.82$.

${ }^{25}$ For an overview of the opportunities for speculation against the pound in 1956, which included leads and lags in trade payments, nonresident capital transactions, and capital transactions by U.K. residents within the sterling area, see Klug and Smith (1999), p. 185. For the rationale and origins of the reserve target, see ibid., p. 192.
} 
Without an understanding of the importance that British officials ascribed to maintaining the sterling parity, Britain's total dependence on U.S. support for its Suez operations is difficult to comprehend. If devaluation or floating had been viable, the United Kingdom could have resisted external financial pressures for long enough to wage what likely would have been an effective military campaign against Egypt. Both of those options, however, were categorically rejected by Macmillan, and even more strongly by the Governor of the Bank of England, Cameron F. Cobbold. Significantly, they saw the consequences as spilling over from economics into political and diplomatic relations. In Cobbold's view, devaluation-"only" seven years after the last one, in 1949- "would probably lead to the break-up of the sterling area (possibly even the dissolution of the Commonwealth), the collapse of [the European Payments Union], a reduction in the volume of trade and currency instability at home leading to severe inflation." Consequently, "we should regard a further devaluation of sterling as a disaster to be fought with every weapon at our disposal." Although Macmillan knew full well that they could not hold the pound at $\$ 2.80$ without U.S. support and that such support was not likely to be offered, he expressed his complete agreement with these views. ${ }^{26}$

For the United Kingdom, therefore, the need for assistance from the IMF resulted not from economics but from the psychological impact of a political crisis on financial markets. Eden's commitment to oppose Nasser in circumstances where victory was highly uncertain shifted market sentiment against sterling at a time when the Bank of England was known to have only a small cushion of liquid dollar-denominated claims. The U.K. authorities underestimated the threat from market speculation and focused instead on official holdings. For some months before Nasser nationalized the canal, the Bank of England had been preparing to protect sterling against a flare-up in the Middle East by blocking Egyptian accounts. When sterling came under immediate selling pressure in the wake of the nationalization on July 26, 1956, British officials suspected that Egypt was dumping sterling on the market, and they moved quickly to prohibit the transfer of sterling for Egyptian pounds. ${ }^{27}$ Not surprisingly, this gnat-swatting exercise did little to stem the pressure. Reserves dripped away gradually over the next four months and would have approached the self-imposed floor by end-October except for the serendipitous receipt of $\$ 177$ million in September from the sale of the Trinidad Oil Company to an American firm (Figure 1).28

${ }^{26}$ PRO, T236/4188, note from Cobbold to Macmillan (October 17, 1956), with handwritten response from Macmillan (October 24); and minutes of a meeting between the two (November 16). For a detailed study of Anglo-American relations during the Suez crisis, see Lucas (1996).

${ }^{27}$ See Fforde (1992, p. 550) on the initial planning, Kunz (1991, p. 78) on the July reaction, and Macmillan (1971, pp. 109-11) for an insider account of the July decisions. The specific controls imposed are described in "United Kingdom-Part II, Background Material for 1956 Consultation," SM/57/14 (February 9, 1957); IMF/CF, C/United Kingdom/420.1, "Exchange Restrictions Consultations 1956."

${ }^{28} \mathrm{Net}$ reserves as plotted in Figure 1 are adjusted for certain extraordinary transactions: balances due and paid through 1958 on U.S. wartime loans, the 1956 IMF drawing, receipts from the sale of the Trinidad Oil Company, and the 1957 U.S. loan. The gap between gross and net at the beginning of 1955 is $\$ 698$ million, the amount that was due to be paid on U.S. loans over the next four years. The gap at the end of 1958 is $\$ 1,092$ million, the sum of the IMF and U.S. Export-Import Bank credits, Trinidad Oil receipts, and a 1957 waiver of interest due on U.S. loans. For daily reserve movements during the second half of 1956, see Klug and Smith (1999), Figure 3. Those data also appear to exclude some extraordinary transactions, most notably the IMF drawing. 
Figure 1. British Gold and Dollar Reserves, 1955-58

(in millions of U.S. dollars; end of month)

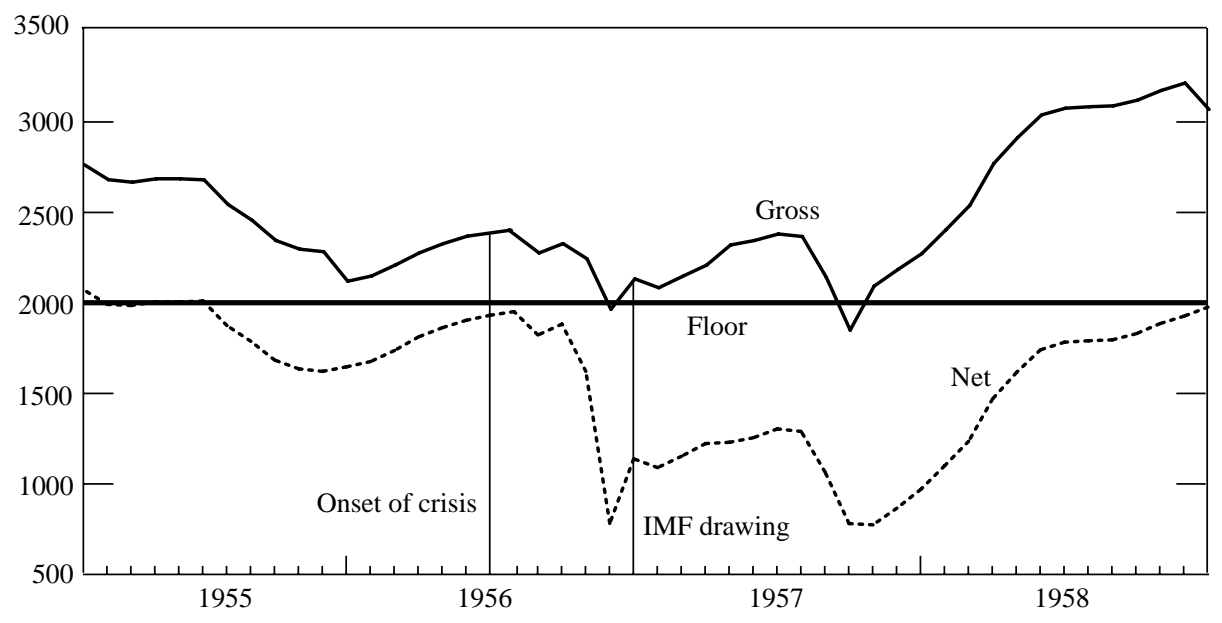

Source: U.K. Central Statistical Office, Monthly Digest of Statistics. For definition of net reserves, see footnote 25 .

Britain's first line of defense was intervention in the form of spot purchases of sterling in the foreign exchange market. As Klug and Smith (1999, pp. 199-200) have noted, the Bank of England- "in the Keynesian spirit of the time"—did not believe that the classic monetary response of raising short-term interest rates would do any good. Tightening the budget would help, but not quickly enough to resolve a financial crisis: even in 1956.

It was clear almost immediately to both the Treasury and the Bank that a second line of defense was needed to protect the reserve floor. Despite the U.S. opposition to the European effort to force Egypt to return control of the canal, Macmillan hoped to build on Britain's and his own "special relationship" with the United States (his mother was American) to persuade Washington to help him support sterling. Either they could temporarily waive the interest due on lend-lease credits advanced during the Second World War, or they could provide new loans through the Export-Import Bank. If that line of defense failed, Macmillan expected to be able to count on the apolitical tradition of the IMF to draw the modest amounts to which Britain was virtually entitled. More important, though with less than complete logical consistency, he expected to be able to build on Britain's informally accepted special status in the IMF - as one of the two major founding countries and the second-largest member-to draw much larger amounts and to the fullest possible extent. ${ }^{29}$

${ }^{29}$ As late as 1967 , long after performance criteria (required policy adjustments) had become standard practice in IMF stand-by arrangements, it approved arrangements for the United Kingdom without formal policy conditions. Prior to 1956, the United Kingdom had drawn small amounts on four occasions in 1947-48 but had maintained a credit position since November 1953. 
Macmillan put the IMF card on the table just two weeks after the nationalization of the canal, when he told a Treasury meeting "that he was proposing to ask Australia to sell us some gold, and was also considering whether we should not withdraw dollars from the International Monetary Fund." Over the next two weeks, the Treasury considered whether they could try to draw on the IMF even without U.S. support. A simple majority of votes cast in the Executive Board, which was all it would take, was conceivable but very unlikely against U.S. opposition. All seven European Directors, Australia, and Canada were expected to vote in favor of a British drawing. The U.S. and Egyptian Directors and all three from Latin America would probably oppose it. Only if the remaining three-from China, India, and Japan - could all be persuaded at least to abstain would the motion carry. That prospect was quite dim. Even worse, as Macmillan readily acknowledged, once investors knew that the IMF resources were sterling's last line of defense, even a large stand-by would "not do much to put off the day" when the parity would have to be abandoned. American support was therefore essential. ${ }^{30}$

The occasion for testing sterling's defenses was the same one seized by the other three countries for approaching the IMF: the Annual Meetings of the IMF and World Bank Governors in Washington at the end of September. Macmillan, participating as the Governor in the IMF for the United Kingdom, met privately with his American counterpart, Treasury Secretary George M. Humphrey; with the Secretary of State, John Foster Dulles; and with President Eisenhower. ${ }^{31}$ Discussions with both Humphrey and Dulles touched on the prospects for U.S. financial support, especially through waivers of interest payments on wartime credits. Only with Humphrey did the possibility of getting IMF credits figure prominently. ${ }^{32}$ Although Humphrey clearly gave Macmillan no promises, the Chancellor interpreted his and the other officials' comments as an assurance that some form of U.S. financial aid would be forthcoming after the presidential election of November 6 . He therefore returned home confident that he could count on his American friends to help him maintain "the strength of sterling." As he recalled bitterly in his memoirs, "[t]here was no hint, at this time, of any difficulty being put in our way, or of financial backing to Britain not being available in full, whatever the circumstances" (Macmillan, 1971, p. 135).

Macmillan took no further action during October, as the Bank of England continued to sell off its dollar reserves to maintain the $\$ 2.80$ exchange rate and the Cabinet continued to prepare for war. Through this period, the Bank's reserves were not so much under attack as merely dripping away. Israel's invasion of the Sinai on October 29 and the opening of the Franco-British military offensive two

${ }^{30} \mathrm{PRO}, \mathrm{T} 236 / 4188$, note from Norman Brook to Edward Bridges (August 9, 1956), and note from Leslie Rowan to Macmillan (September 21) with handwritten response from Macmillan (September 25). For the Treasury's expectations on how each Director might vote, see T236/4189, cable from Harold Caccia to the Foreign Office (November 9). Brook, Bridges, and Rowan were senior Treasury officials, and Caccia was the British Ambassador to the United States. For the distribution of voting power in the IMF in 1956, see Horsefield (1969), Vol. 2, p. 353.

${ }^{31}$ See Kunz (1991), pp. 103-7, and Kyle (1991), pp. 256-58.

${ }^{32}$ See NARA, Records Group 56, Entry 70A6232, Box 78; William Harcourt to Andrew Overby (Assistant Treasury Secretary), "The Chancellor of the Exchequer's talk with the Secretary of the Treasury," September 25, 1956. 
days later solidified U.S. and world opposition and greatly accelerated the drain on reserves, to a pace that clearly constituted a speculative attack (Klug and Smith, 1999, p. 191). On November 2, the United Nations General Assembly overwhelmingly approved a U.S. resolution calling for a cease-fire and withdrawal of forces. Four days later, the British Cabinet bowed to the relentless financial and diplomatic pressure and agreed to a cease-fire.

Although Macmillan persisted in denying that financial pressure was the decisive factor, none of the extensive evidence supports a credible alternative explanation. ${ }^{33}$ Moreover, Macmillan acknowledged in his memoirs that the Cabinet learned during its crucial meeting on November 6 that the United States would not support its "technical" request to draw on the IMF "until we had agreed to the cease-fire" (Macmillan, 1971, p. 164). Exactly how and when the request was made to the U.S. authorities and who conveyed the negative response has never been established. ${ }^{34}$ That ambiguity, however, does not vitiate the conclusion reached by Gorst and Johnman (1997, p. 133), that "it is clear that it was financial pressures that were driving British policy" to accept the cease-fire. The more important ambiguity relates to the policy requirement. As subsequent events demonstrated, the Americans were insisting not just on a cease-fire, as Macmillan claimed, but on full compliance with the UN resolution; that is, on an immediate withdrawal of all troops from Egypt.

With the American obstacle apparently out of the way, attention turned again to how to put together a large enough support package to stop the run on sterling. Cobbold opposed making an immediate approach to the IMF, on the grounds that speculators would interpret it as a sign of weakness unless it was announced as part of a broader package of assistance. Treasury officials were less convinced of the virtues of waiting, since they suspected that the IMF was their only hope. They all agreed, however, that if they were to approach the IMF, they should try to borrow the maximum possible amount, which they expected to be "three tranches," or 75 percent of quota. ${ }^{35}$ Although a few small countries (Burma, El

33"The falling away of reserves was not in itself calamitous.... Although ... I did not conceal the seriousness of the financial situation, this was not the reason for our acceptance of the cease-fire" (Macmillan, 1971, p. 164). Also see Rhodes James (1986), p. 573, which describes financial factors as "decisive" but not "the only factor"; and Fforde (1992), p. 556, which suggests (rather outrageously) that the best way to restore confidence in sterling might have been to forge ahead militarily and capture the canal.

${ }^{34}$ Macmillan (1971, pp. 163-64) claimed that he called "New York" (presumably the Federal Reserve Bank), which referred him to "Washington" (presumably the Treasury), which then sent a reply. Eden (1960) referred to a telephone call from Humphrey to R. A. Butler (Leader of the House of Commons), in which he "made it clear that the United States would not extend help or support to Britain until a definite statement of withdrawal had been made" (p. 572). Although Eden did not specify the date of the call, the context suggests that it would have been around November 6. Fforde (1992, pp. 556 and 563-64) noted the absence of documentary evidence and the improbable timing of the calls and concluded that Macmillan probably never made them. That would imply that Macmillan had already given up on the possibility of gaining U.S. support and that he also made up the story about receiving a reply during the cabinet meeting.

35PRO, T236/4188; Rowan to Roger Makins (Permanent Secretary) [and through him to the Chancellor], "The Reserves, I.M.F. (a standby or drawing), and the Waiver" (October 26, 1956); and minute by Rowan of a meeting between Macmillan and Cobbold at the House of Commons (October 30); T236/4189, note from Makins to Macmillan (November 9); and record of a meeting in Makin's office (November 12). Kyle (1991), p. 500, misinterprets Cobbold's "three tranches" suggestion as implying a drawing of 100 percent of quota, rather than 75 percent. 
Salvador, and the Philippines) had drawn their full quotas, none of the large countries had gone higher than 50 percent. A drawing by the United Kingdom of 75 percent would total nearly $\$ 1$ billion, almost four times the size of the previous record, the October stand-by for France. Nonetheless, both the Treasury and the Bank were determined to try to get it.

Curiously, the IMF staff played a largely passive role in this developing drama. A staff mission team was in London in late November, but it was there only to conduct the routine annual consultations. The mission does not seem to have questioned the authorities' determination to maintain the exchange rate at $\$ 2.80$ (though it may have done so in high-level meetings, without written documentation), nor the stance of macroeconomic policies. Nor did it raise formally the question of whether a drawing from the IMF might be appropriate or necessary. The issue, after all, was political rather than economic: the exchange rate level was appropriate if temporary financing could be secured. Although the mission was led by the highly respected Irving Friedman, Director of the Exchange Restrictions Department, none of the internal Treasury correspondence relating to Suez even mentioned the ongoing discussions with the staff. The mission completed its technical work in five days, but the consultations were then suspended until after the matter of financial assistance was resolved in Washington. ${ }^{36}$

Even if British officials took no notice of the staff, they were anxious to ensure that the IMF's management would be at least neutral if the United States continued to oppose them. They were greatly reassured when the Managing Director-elect, Per Jacobsson, paid a call on Cobbold on November 22, while on his way to take up his duties in Washington. Although Jacobsson seems not to have made any promises, Cobbold was quite pleased with their meeting. "You may like to know," he reported to Macmillan and the Treasury, "that Dr. Jacobsson agrees, both in U.K. interests and in world interests, with our policy, and that he considers that our present exchange rate is fundamentally sound on an international economic basis." 37

Jacobsson in fact had been even more persuaded by Cobbold than the Governor realized. Jacobsson's biography, written by his daughter largely on the basis of his diary, conveyed his views in dramatic terms:

When PJ walked into his office at the IMF, on Monday 3 December 1956, he was determined that the financial assistance the UK would receive was to total $\$ 1,300 \mathrm{~m}$. The speculation against sterling ... could only be stopped if really large funds were available. The alternative, as he learnt when passing through London, would be a floating sterling rate, the consequences of which would be unpredictable. There would therefore have to be maximum financial assistance. This was the conclusion PJ reached during the boat journey which took him from his job at the BIS to his new post at the IMF. ${ }^{38}$

\footnotetext{
${ }^{36}$ The mission documentation is in IMF/CF, C/United Kingdom/420.1, "Exchange Restrictions Consultations 1956."

${ }^{37}$ PRO, T236/4190; Cobbold to Makins (November 22, 1956).

38Jacobsson (1979), p. 283.
} 
Meanwhile, Macmillan still lacked American support, and he was forced into supplication to get it. (The Prime Minister, Eden, had by now withdrawn to Jamaica in poor health.) Despite the cease-fire, British and French troops remained on the ground in Egypt. The U.S. government wanted them out, and Britain's need for financial assistance gave them the perfect lever to force an immediate withdrawal. Macmillan tried unsuccessfully to arrange a meeting with Humphrey in late November, but he managed to convey to him through William Harcourt and Harold Caccia (Executive Director and Ambassador, respectively) that a failure to support sterling could have catastrophic political consequences, including a triumph for international communism. Such threats doubtless seemed fanciful to Humphrey, who replied simply that the United States would support Britain when the latter was "conforming to rather than defying the United Nations." Even then, he warned that a drawing on the IMF beyond the first credit tranche (that is, more than $\$ 561$ million) would be problematic. A larger drawing, Humphrey argued, could cause "a run on the Monetary Fund, which might be as serious as a run on sterling." 39

Britain faced a firm deadline for obtaining approval of a financial support package. On December 4, Macmillan would have to announce that a massive loss of reserves in November ( $\$ 279$ million, net) had pushed the balance below the $\$ 2$ billion floor. Without support, the parity would have to be abandoned. Humphrey was on a short vacation and would not return to Washington until December 3, the same day that Per Jacobsson was to arrive for his first day as Managing Director. If the pound was to be saved, it would have to be saved on December 3.

Left with no alternative, the British Cabinet accepted the second half of the UN resolution and set a deadline of December 22 for a full troop withdrawal. Harcourt and Caccia then called on Humphrey to find out how much financial aid this capitulation had purchased. The extent of bilateral support was still vague but now could be counted upon and publicly announced as forthcoming. ${ }^{40}$ Of more immediate and concrete concern was the amount of IMF credits to be put at Britain's disposal.

At the beginning of the meeting on December 3, Secretary Humphrey continued to insist that his government could not support a large-scale support operation from the IMF. The U.S. Treasury would have to borrow the dollars to finance the operation, which he feared would put upward pressure on interest rates in the New York money market. Moreover, such a large operation, in his view, would violate the IMF's own operating principles and could lead other countries to submit similar requests. Then, quite suddenly and to the astonishment of his

${ }^{39}$ PRO, T236/4190, cables from Caccia to the Foreign Office (November 27, 1956). The appeal on grounds of stopping the spread of communism came only after Caccia dissuaded Macmillan from stressing the dangers to the sterling area, which clearly would have made even less of an impression on the Americans.

${ }^{40}$ Negotiations led quickly to agreement on a $\$ 500$ million loan from the U.S. Export-Import Bank, which was announced on December 21 and executed the following March. More protracted negotiations led in 1957 to a loosening of the conditions under which Britain could reschedule interest payments due on outstanding lend-lease credits. See Kunz (1991), pp. 162 and 181. 
British visitors, he swept aside those worries and reversed course. According to Caccia,

Humphrey, who was clearly thinking aloud, then suddenly switched his point of view. He said that if we went beyond the first two tranches, for which there was precedent, he was not sure that it would not be better for us to go for all four tranches. The object was to demonstrate beyond all doubt to the world that sterling was supported, and had resources sufficient to withstand any attack. Would it not be better to draw the first two tranches and get a standby for the other two? ${ }^{41}$

The crisis was over. When Macmillan revealed the November reserves losses in the House of Commons the next day, he was able simultaneously to announce that Britain would be making "an immediate approach" to the IMF as part of a broad effort to "fortify" reserves, although he was still circumspect regarding how much of the U.K. quota might be available. ${ }^{42}$ Speculators against sterling still had a one-way bet, but the odds were now pretty long against it.

All that remained was for the Executive Board to ratify the arrangements that had been agreed bilaterally between the two great powers. Success seemed assured, because-as indicated by the quotation given above-Per Jacobsson shared Humphrey's view that a $\$ 1.3$ billion package was needed to stem speculation against the pound. On December 6, as the Board meeting approached, Jacobsson wrote in his diary that "since the confidence factor played such a great role the amounts ought to be high enough to impress the market." The two men also agreed that this operation should be a special case. Humphrey calculated that no other country would dare ask for such massive support and, even if one did, it was manifest that the IMF could not afford to repeat it very often. As the Managing Director observed in a speech on December 6, the IMF "cannot fuel all the people all the time."43

Two potential roadblocks remained. First, the United Kingdom was technically in violation of the IMF's Articles of Agreement for having failed to notify it officially of the imposition of exchange controls against Egypt at the end of July. British officials were aware that Egypt could choose to delay the funding request by raising a legal challenge. In the event, Egypt did not do so, and the required notification was made a few months later (see above, footnote 27 ).

The second, and potentially more troublesome, obstacle was the prohibition in the Articles against lending to finance a large and sustained capital outflow. On

${ }^{41}$ PRO, T236/4190, cable from Caccia to the Foreign Office (December 3, 1956). Frank Southard, the U.S. Executive Director, later wrote that Humphrey had cleared the four-tranche proposal with him before floating it to the British, saying that "he had always believed that if a big job was to be tackled, one should go all out." See Southard (1979), p. 20.

${ }^{42}$ The U.K. quota in the IMF was $\$ 1,300$ million, and the country had a credit balance (a gold tranche position) of 18 percent of quota, or $\$ 236.5$ million. The proposal was to make up a package totaling 100 percent of quota, comprising an immediate drawing of $\$ 561.5$ million and a 12-month stand-by arrangement for $\$ 738.5$ million. If fully utilized, the United Kingdom would have had a debit position of 82 percent of quota, but it would have faced an obligation to repay the full 100 percent in credits (see footnote 3 ).

${ }^{43}$ Both quotations are from Jacobsson (1979), p. 285. 
December 5, Harcourt met with Jacobsson and several senior IMF staff in the Managing Director's office, to discuss strategy for handling the financing request. They acknowledged that the credits would finance a capital outflow, but Jacobsson suggested (rather stretching the point) that to the extent that these flows were in the form of "leads and lags" in payments, they were linked directly to the financing of the current account. Harcourt then made a more coherent argument: without this financing, it would be difficult for Britain to maintain progress toward establishing full convertibility of sterling for current account transactions. ${ }^{44}$ Until this point, the IMF had followed the lead of its founding fathers (John Maynard Keynes and Harry Dexter White) in regarding the current and capital accounts as essentially separable phenomena. Because Britain's role as an international banker made that separation impossible, this rescue operation was about to break the mold.

The staff report that was circulated to Executive Directors two days later stated explicitly that financing was needed for the capital account, not the current account. It also raised the specter of systemic repercussions if the IMF failed to act on the British request:

The Staff believes that the policies designed to restrain internal demand...will be adequate to maintain the United Kingdom's competitive position and to overcome the temporary payments difficulties and trade dislocation which the U.K. economy will experience in the coming months. However, given the status of sterling as an international currency and the United Kingdom's role as banker for a large trading area, its efforts to overcome its balance of payments difficulties and to follow a policy of extending the area of freer trade and payments could be undermined if confidence in sterling were weakened by further sustained losses of monetary reserves. Moreover, the danger would arise of serious repercussions on the volume of world trade and on the progress made in freeing trade and payments from external restrictions. ${ }^{45}$

The Executive Board accepted this rationale and approved the request with one abstention (Egypt). ${ }^{46}$ Britain immediately made the drawing of $\$ 561$ million

\footnotetext{
${ }^{44}$ Minute of the meeting, by the Personal Assistant to the Managing Director (December 6, 1956); in IMF/CF, C/United Kingdom/1760, "Stand-by Arrangements 1952-1960."

${ }^{45}$ See "Use of the Fund's Resources-United Kingdom" (EBS/56/44, Sup. 1, December 7, 1956), p. 6; in IMF/CF, C/United Kingdom/1760, "Stand-by Arrangements 1952-1960." A year later, the IMF’s Deputy Director of Research, Jacques J. Polak, stated this rationale even more clearly in an internal memorandum: "The main reason for the U.K. drawing last year and the only reason for the standby was the need to counteract speculative capital movements... it is obvious that the unprecedentedly large Fund assistance was given to counteract and, insofar as possible by its announcement effect to forestall, a flight of capital from sterling" (memorandum dated November 29, 1957; op. cit.).

${ }^{46}$ The Executive Director from Egypt, Ahmed Zaki Saad, absented himself from the meeting. The constituency's abstention was announced by his Alternate, Albert Mansour (also from Egypt), who noted for the record that 3 of the 12 countries in the diverse constituency (Lebanon, Pakistan, and the Philippines) supported the British request. (IMF rules do not permit the splitting of votes within a constituency.) See IMF/CF, minutes of Executive Board Meeting 56/59 (December 10, 1956).
} 
to replenish its reserves and announced that it had another $\$ 739$ million available on stand-by.

Both the U.K. and the U.S. authorities attached great importance to the goal of not drawing on the stand-by arrangement. It was important to Britain for generating confidence in sterling and to the U.S. authorities for limiting the amount of dollar financing that they had to arrange. At a meeting in Paris the day after the Executive Board approved the arrangement, Humphrey stressed to Macmillan that Britain could not "afford to draw a single penny of the standby" without damaging confidence. Macmillan agreed and hoped that they had put enough money "into the shop window" to make a further drawing unnecessary. In fact, they had. The announcement soon stopped - though it did not reverse- the reserve outflow, and for the next several months British reserves fluctuated above the $\$ 2$ billion floor (Figure 1). New concerns about loose macroeconomic policies led to a resumption of reserve outflows in the second half of 1957 and induced the government to negotiate a renewal of the stand-by arrangement in December, but at no time did they have to draw on it. ${ }^{47}$

\section{Consequences}

The most obvious consequence of the IMF's involvement in the Suez crisis is that it put it on the map as an episodic international lender. ${ }^{48}$ For the first time, the IMF had played a significant role in helping countries cope with an international crisis. Subsequently, it was called upon repeatedly to deal with other shocks to the financial system, notably the sterling crises and the gold pool crisis of the 1960s, the oil shocks of the 1970s, the developing country debt crisis of the 1980s, and the financial crises in Mexico, Russia, and Asia in the 1990s (Figure 2). Although the IMF also began to lend regularly to help countries cope with the temporary payments effects of economic imbalances, that ongoing activity was quite small in amount relative to the occasional spurts occasioned by financial crises.

What has been lost in the previous discussions of these events is the striking modernity of the 1956 sterling crisis. When the "tequila" crisis hit Mexico in 1995, the IMF's Managing Director, Michel Camdessus, called it the "first financial crisis of the twenty-first century." Virtually all of the elements of that situation that made it seem newly complex were, however, present in the Suez crisis 40 years earlier.

First, what the United Kingdom faced in 1956 was almost purely a speculative attack on a stable currency against a backdrop of reasonably sound economic policies. That is, it was a financial and not an economic crisis, and its primary effect was on the capital account of the balance of payments. Mexico in 1995 had a current account deficit and faced a much greater need for economic adjustment, and it therefore lacked the financial resources to preserve its fixed exchange rate,

\footnotetext{
${ }^{47}$ See NARA, Records Group 56, Entry 70A6232, Box 81; "Secret Record of a Discussion at the Hotel Talleyrand, Paris, at 3 p.m. on Tuesday, December 11th, 1956." The $\$ 2.80$ rate held for another decade, until the 1967 devaluation to $\$ 2.40$.

${ }^{48}$ See James (1996), pp. 102-5 and 137, and Boughton (2000).
} 
Figure 2. IMF Lending, 1948-99

(in percent of world imports)

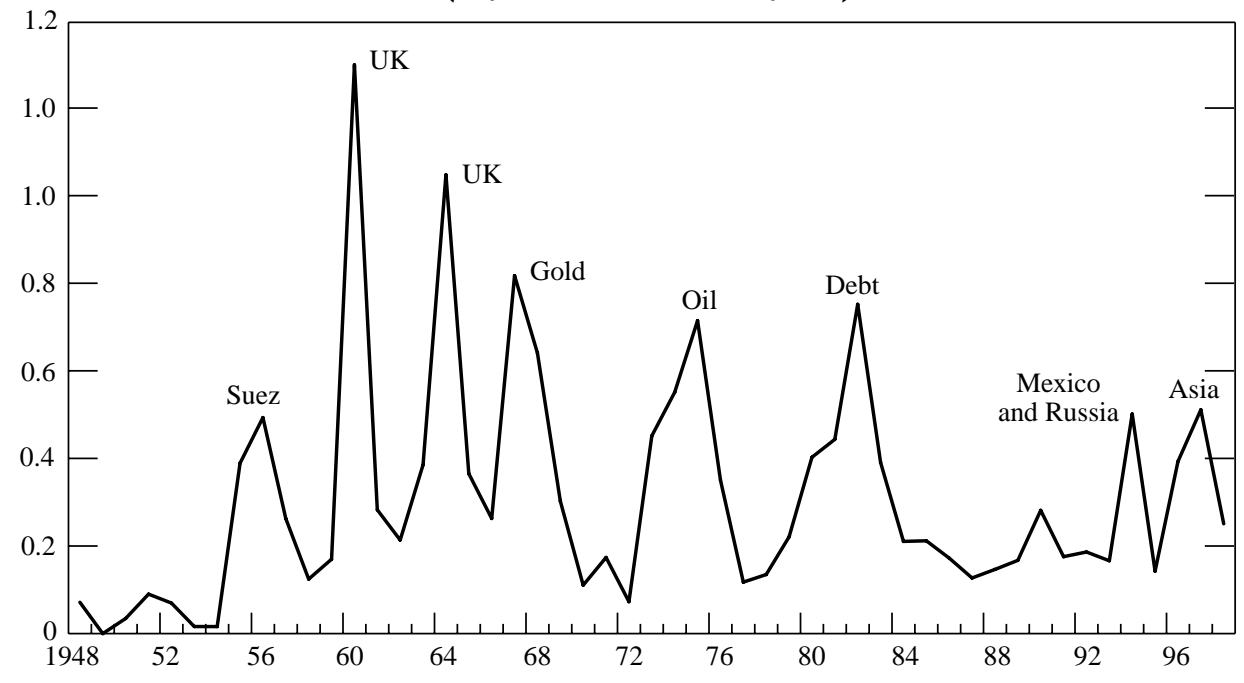

even with $\$ 40$ billion in financial commitments from the IMF and other external creditors. In both cases, however, the most pressing requirement for resolving the crisis was to stem the speculative attack.

Second, in both cases the crisis was precipitated by a clash of policy goals, between maintaining a stable exchange rate and simultaneously establishing open markets for the currency. The United Kingdom in 1956 was on a path toward establishing full convertibility for sterling. Mexico in 1995 had already done so but was in danger of being forced to reestablish exchange controls to avoid a disastrous depreciation of the peso exchange rate. What was new in the 1990s was the relevance of this conflict for a country with an emerging market and a nonreserve currency. In the 1950s, even the potential for market speculation was relevant only for a very few countries.

Third, a rapid response was essential. Despite the limited convertibility of sterling in 1956, Britain began losing reserves rapidly after the United Nations condemned its invasion of Egypt in early November. The IMF had to respond by early December if Britain was to avoid floating the pound. The length of time between the onset of the attack and approval of the financial package was almost the same as in the peso crisis of 1995.49

Fourth, the key in both cases was to post a large enough number to impress financial markets, convince speculators that a bet against the currency could not be won, and persuade investors to keep their money in the country. In the tequila

${ }^{49}$ Mexico initially devalued the peso on December 20, 1994. It applied for an IMF stand-by arrangement on January 5, and the request was approved on February 1 . The two circumstances, however, were not fully comparable in that the U.K. arrangement did not require the negotiation of policy conditions. 
crisis, the IMF was forced to increase its commitment by $\$ 10$ billion after the U.S. Congress refused a request from the Clinton administration for a package of loan guarantees. Markets had come to expect a total multilateral package of $\$ 40$ billion, and the only way to avoid a resumption of panic selling was to assemble commensurate financing. In 1956, a similar psychological floor was created by the known commitment of the British government to maintain reserves of at least $\$ 2$ billion. A commitment by the IMF had to be large enough to protect that floor if it was to do any good at all. The 1956 commitment was unprecedented in absolute size; the 1995 package was unprecedented both in size and in relation to the borrower's quota. In both cases, the required size of the package was determined by market psychology, not economics.

Fifth, in neither case could the return of private sector investors be assured, but in both cases it eventually emerged spontaneously. Britain was unable to restore the level of foreign exchange reserves, net of drawings from the IMF, until well into 1958. Similar delays characterized the financial crises of the second half of the 1990s, as the initial effect of multilateral rescues was to replace rather than to restore international private investment. These experiences contrast with the more tightly controlled handling of the Latin American debt crises of the 1980s, when "concerted lending," multiyear reschedulings, and complex "menus" for restructuring existing debts were commonly invoked. With a longer focus, recent experience appears to be both more normal and more viable.

Sixth, the IMF's involvement in both cases was necessitated by the unwillingness of the United States to provide sufficient resources bilaterally, despite its acknowledged self-interest in a successful resolution of the crisis. In 1956, even after the United Kingdom had acquiesced to American political demands, all that the U.S. government could promise in the short run was a modest loan from the Export-Import Bank. In 1995, all that it could promise to Mexico was $\$ 20$ billion in short-term credits through the Exchange Stabilization Fund. In both cases, a much larger multilateral package would have to be assembled to end the crisis, and the IMF was the institution that was best placed to do so.

Because no one recognized these parallels in 1995, the Mexican case appeared to be a much more radical departure from past practice than it was. When the IMF made an even more rapid and large-scale commitment to Korea in the midst of the Asian financial crisis in 1997, it was building on a tradition that extended back not 2 years, but more than 40 .

\section{REFERENCES}

\section{Archives}

IMF/CF International Monetary Fund, Central Files (Washington, DC)

NARA U.S. National Archives and Records Administration (College Park, Maryland)

PRO U.K. Public Records Office (Kew, England) 


\section{James M. Boughton}

\section{Publications}

Boughton, James M., 2000, "From Suez to Tequila: The IMF as Crisis Manager," Economic Journal, Vol. 110 (January), pp. 273-91.

_ - 2001, Silent Revolution: The International Monetary Fund, 1979-1989 (Washington: International Monetary Fund).

Eden, Anthony, 1960, The Memoirs of Sir Anthony Eden: Full Circle (London: The Times Publishing Company).

Farnie, Douglas, 1969, East and West of Suez: The Suez Canal in History, 1854-1956 (Oxford: Clarendon Press).

Fforde, John, 1992, The Bank of England and Public Policy, 1941-58 (Cambridge, England: Cambridge University Press).

Gorst, Anthony, and Lewis Johnman, 1997, The Suez Crisis (London and New York: Routledge).

Horsefield, J. Keith, 1969, The International Monetary Fund 1945-1965: Twenty Years of International Monetary Cooperation (Washington: International Monetary Fund).

International Monetary Fund, 1956, Summary Proceedings of the Eleventh Annual Meetings of the Board of Governors, September 1956 (Washington: International Monetary Fund).

- 1957, Annual Report of the Executive Board for the Financial Year Ended April 30, 1957 (Washington: International Monetary Fund).

Jacobsson, Erin E., 1979, A Life for Sound Money: Per Jacobsson, His Biography (Oxford: Clarendon Press).

James, Harold, 1996, International Monetary Cooperation Since Bretton Woods (Washington: International Monetary Fund; New York: Oxford University Press).

Johnman, Lewis, 1989, "Defending the Pound: The Economics of the Suez Crisis, 1956," in Post-War Britain, 1945-64: Themes and Perspectives, ed. by Anthony Gorst, Lewis Johnman, and W. Scott Lucas (London and New York: Pinter Publishers).

Klug, Adam, and Gregor W. Smith, 1999, "Suez and Sterling, 1956," Explorations in Economic History, Vol. 36, pp. 181-203.

Kunz, Diane B., 1991, The Economic Diplomacy of the Suez Crisis (Chapel Hill: University of North Carolina Press).

Kyle, Keith, 1991, Suez (New York: St. Martin's Press).

Lucas, W. Scott, 1996, Divided We Stand: Britain, the United States and the Suez Crisis (London: Hodder and Stoughton).

Macmillan, Harold, 1971, Riding the Storm: 1956-59 (New York: Harper and Row).

Rhodes James, Robert, 1986, Anthony Eden: A Biography (London: Weidenfeld and Nicolson).

Shlaim, Avi, 1997, "The Protocol of Sèvres, 1956: Anatomy of a War Plot," International Affairs, Vol. 73, No. 3, pp. 509-30.

Southard, Frank A., Jr., 1979, The Evolution of the International Monetary Fund, Essays in International Finance, No. 135 (Princeton, New Jersey: Princeton University Press). 